\title{
Didaktické řídicí styly ve výuce tělesné výchovy na 2 . stupni základní školy: postoje a zkušenosti učitelů
}

\author{
Teaching styles in lower-secondary physical education lessons: \\ teachers' attitudes and experiences
}

\author{
Jiří Sliacky \\ Fakulta sportovních studií, Masarykova univerzita, Brno
}

\begin{abstract}
Abstrakt
Příspěvek prinnáší výsledky druhé části výzkumu využití didaktických řídicích stylů ve výuce tělesné výchovy na 2. stupni základní školy, jehož cílem je analyzovat postoj vybraných učitelů k různým didaktickým rídicím stylům v kontextu priorit tělesné výchovy a vlastních zkušeností z výuky. Cílem tohoto výzkumného šetření je zasadit výsledky, popisující jaké didaktické rídicí styly jsou ve výuce využívány, do širších souvislostí v podobě učitelova uvažování. Metodou sběru dat pro analýzu bylo strukturované interview, které se skládalo ze dvou hlavních částí. První byla rozprava o prioritách a cílech výuky tělesné výchovy, skutečně využívaných didaktických rídicích stylech a zkušenostech s těmito styly. Druhá část potom byla tvořena rozborem konkrétní výukové situace z videozáznamu, pořizeného pro první část výzkumu, se zaměřením na didaktické uchopení učiva. Výsledky interview ukázaly, že ačkoli ani jeden z dotazovaných učitelů didaktické rídicí styly jako didaktickou teorii nezná, přesto s některými principy této teorie dokáže intuitivně pracovat a uvědomuje si jejich př́nos.
\end{abstract}

\begin{abstract}
The paper brings the results of the second part of the research of the use of teaching styles in Physical Education lessons at the lower-secondary schools, whose objective is to analyze the attitude of the selected teachers to different teaching styles in the context of the priorities the Physical Education and their own experience of teaching. The purpose of this research is to place the results of the investigation, describing what the teaching styles are used in teaching, in the broader context teachers thinking. The data collection method for the analysis was a structured interview, which consisted of two main parts. The first debate on the priorities and objectives of Physical Education, really used of teaching styles and experiences with these styles. The second part consisted of an analysis of specific teaching situation from the video, captured for the first part of the research, focusing on the didactic grasp of subject matter. The results of interviews showed that although none of the interviewed teachers teaching styles as didactic theory doesn't know, yet with some of the principles of this theory can intuitively operate and be aware of their benefit.
\end{abstract}

Klíčová slova: Tělesná výchova, didaktický řídicí styl, učitel, interview, analýza, kategoriální systém.

Keywords: Physical education, teaching style, teacher, interview, analysis, system of categories.

\section{ÚVODEM}

Tělesná výchova a její výuka na školách před nás klade stále nové, ale i známé problémy v nových souvislostech, jejichž způsob řešení či naopak přehlížení může ovlivnit kvalitu výuky a směřování tohoto předmětu do budoucna. Problematika zdravotních rizik u žáků a studentů jako např́íklad nadváha, vadné držení těla, celkově nízká fyzická kondice, problematika jejich vztahu k pohybu a pohybovým aktivitám, problematika volby obsahu, forem a metod ve vztahu $\mathrm{k}$ atraktivitě předmětu, to jsou jen některá často diskutovaná a zkoumaná témata. My jsme se 
ve své práci rozhodli otevřít téma, které považujeme za podobně významné, ale které se přitom, podle našeho názoru, netěšilo takovému zájmu z pohledu teorie ani praxe.

Spektrum didaktických řídicích stylů je teorie, řešící didaktickou stránku zprostř̌edkování učebního obsahu žákům či studentům. Jednotlivé styly tedy nejsou nějakými osobní styly a nemají vztah k osobnosti učitele, jeho osobním preferencím či jeho vyučovacímu stylu. Didaktické řídicí styly jsou na všech těchto faktorech zcela nezávislé, nebot se jedná o ryze didaktickou strukturu (Rychtecký \& Fialová, 2004, s. 119). Aplikovat jednotlivé styly tedy pro učitele znamená učení se novým rolím, bez ohledu na jejich osobní vlastnosti a postoje (Tomajko \& Dobrý, 2002, s. 30). Výzkum Mužíka a Hurychové už přitom koncem 20. století experimentálně prokázal, a to právě u učitelů na 2. stupni základní školy, že učení se těmto novým rolím, tedy využivání různých didaktických řídicích stylů, není pro učitele nijak náročné a problematické. Výsledky těchto autorů ukázaly, že učitel je schopen aplikovat i jiný didaktický řídicí styl, než který byl u něho prvotně pozorován, a to „bez velkých príprav a zkušeností, pokud ovšem o to má zájem“ (Mužík \& Hurychová, 1994, s. 19). A výsledek ochoty k tomuto prrístupu, $\mathrm{k}$ této otevřenosti, potom jasně konkretizuje Dobrý (2007), který uvádí, že „učitelé, kteří si osvojili spektrum, jsou schopni měnit své chování podle potřeby, přizpůsobovat se potřebám žáka, měnit pohled na učivo a edukační cíle“ (s. 10).

Výše shrnuté poznatky nás vedly $\mathrm{k}$ tomu, abychom se ve své práci nezabývali pouze zjištováním reálného využití jednotlivých didaktických řídicích stylů v současné školní praxi, ale abychom se pokusili získat a popsat tuto problematiku i z pohledu samotných učitelů. Přinést tedy zjištění, která by mohla pomoci přesněji interpretovat deskriptivní data výzkumu a prohloubit tak naše pochopení této problematiky. Samotnou teorií spektra didaktických řídicích stylů se v této práci detailněji zabývat nebudeme. Souhrn jejích hlavních bodů a tezí uvádí ve své práci Dobrý (2007, s. 8-15), její úplný popis potom poskytují samozřejmě autoři Mosston a Ashworthová (2008) ve své publikaci Teaching Physical Education.

\section{VÝCHODISKA VÝZKUMNÉHO ŠETŘENÍ}

Hlavním cílem první části našeho výzkumu bylo určit, jaké didaktické řídicí styly učitelé ve vybraných jednotkách tělesné výchovy na 2 . stupni základní školy využívají. Data byla získána analýzou videozáznamů jednotlivých vyučovacích jednotek, které byly kódovány za pomoci vytvořeného kategoriálního systému. Výsledky ukázaly, že v zaznamenaných vyučovacích jednotkách učitelé využívali pouze první dva styly spektra, a sice styl př́kazový a styl praktický.

V návaznosti na tyto výsledky jsme se pokusili pomocí strukturovaného interview, které jsme vedli př́mo s jednotlivými účastníky výzkumu - učiteli, odkrýt jejich způsob uvažování o výuce tělesné výchovy, zjistit jejich priority, postoj k různým didaktickým postupům a zkušenosti s nimi a také $\mathrm{v}$ neposlední řadě jejich informovanost o spektru didaktických řídicích stylů jako takovém. K zájmu o uvedené širší souvislosti nás přivedl fakt, že ačkoli hlavním kritériem volby didaktického rrídicího stylu je cíl výuky, reálně tuto volbu ovlivňují i další faktory. Pokládali jsme si tedy otázky: S jakými prioritami učitel do výuky vstupuje? Proč právě s takovými? Je s nimi jeho následná vyučovací činnost v souladu? Proč učitelé využívají jen některé didaktické řídicí styly? A proč nevyužívají i ty ostatní? Mají pocit, že je to zbytečné nebo jim v tom něco brání? Ani získání všech těchto poznatků nám samožrejmě za daných okolností nedovolí jakékoli zobecňování, ale mohou nám pomoci v nastavení zaměření dalších výzkumů a v postihnutí alespoň některých faktorů vzdělávacího procesu v tělesné výchově.

Náš výzkum je součástí projektu tzv. CPV videostudii ${ }^{1}$, v jehož rámci byl realizovaný výzkum výuky vybraných školních předmětů řadou různých tematických analýz. Ve videostudii fyziky

\footnotetext{
${ }^{1}$ CPV videostudie jsou výzkumným projektem Institutu výzkumu školního vzdělávání Pedagogické fakulty Masarykovy univerzity (dřive Centrum pedagogického výzkumu PdF MU, zkratka CPV), jejichž cílem je výzkum procesu vyučování a učení v některých školních předmětech (byla realizována videostudie fyziky, zeměpisu, anglického jazyka a tělesné výchovy).
} 
autor Janík (2007) využil metodu interview ke zkoumání subjektivních teorií učitelů o jejich výuce a předmětu. To se pro nás stalo metodologickou oporou při hledání vhodného výzkumného nástroje a postupu při naplňování našich výzkumných cílů. Subjektivní teorie totiž Janík (2007) chápe jako strukturu vědění, která obsahuje argumenty pro její udržení, a která se utváří v individuálním psychickém procesu a organizuje naše poznání (s. 15). V návaznosti na to pak konstatuje, že „pokud jsou si učitelé svých subjektivních teorií vědomi, mohou na jejich základě odborně zdůvodnit své pedagogické rozhodování a jednáni“" (s. 15). Tato konstatování nás vedla k závěru, že učitelovi subjektivní teorie jsou velice cenným zdrojem dalších informací o zkoumané problematice a učinili jsme $\mathrm{z}$ nich tedy předmět zájmu našeho výzkumného šetření.

Zjištování postojů učitelů $\mathrm{k}$ využivání různých didaktických řídicích stylů pomocí interview je součástí i práce Salvarové, LeBlanca, Bognára a Birové (nedatováno). Tito autoři se zaměřili na to, jak vnímají učitelé tělesné výchovy na základních školách působení jednotlivých didaktických řídicích stylů na psychomotorickou, emoční, sociální a kognitivní stránku jejich žáků. Celkem 42 mad’arských učitelů tělesné výchovy z Budapeště se ve strukturovaném interview vyjadřovalo, do jaké míry použití jednotlivých stylů rozvíjelo z jejich pohledu každou z výše uvedených stránek jejich žáků (Salvara, LeBlanc, Bognár \& Biro, nedatováno, s. 1-3). Výsledky ukázaly, že učitelé vnímají rozdíl mezi reprodukčními a produkčními styly spektra v tom smyslu, že reprodukčním připisují větší vliv na psychomotorickou stránku žákủ (výraznou výjimkou byl jen styl reciproční, u kterého připsali učitelé největší vliv stránkám sociálním a emočním), zatímco u produkčních vnímají jako zásadní ovlivňování emočních a kognitivních stránek. $Z$ toho můžeme vyvodit, že si zúčastnění učitelé uvědomovali přínos stylů v kontextu cíle výuky, jinými slovy jedinečnost stylů ve vztahu k cílům, které mohou naplňovat. Přirozeně tak vyplývá i potřeba využití různých stylů, aby mohly být naplňovány cíle z různých oblastí. Zde je ale nutné podotknout, že na rozdíl od našeho výzkumného šetření, byli všichni tito učitelé ve využívání různých didaktických řídicích stylů nejprve proškoleni a znali tak jednak celou teorii podrobně a jednak s ní měli následně i praktickou zkušenost. $V$ tomto pohledu jsme v našem výzkumném šetření měli zcela opačnou výchozí pozici.

\section{CÍLE, VÝZKUMNÉ OTÁZKY A ÚKOLY}

\section{Cíle a výzkumné otázky}

Cílem naší práce bylo analyzovat postoj vybraných učitelů k využivání různých didaktických řídicích stylů v kontextu uvědomovaných priorit tělesné výchovy a osobních zkušeností z výuky. Na základě stanoveného cíle jsme následně formulovali i hlavní výzkumnou otázku.

\section{Jak učitelé nahlížejí na různé didaktické řídicí styly a jejich využití v praktické výuce?}

Abychom obsáhli co největší prostor této problematiky a naplnili stanovený cíl, odvodili jsme

z hlavní výzkumné otázky ještě čtyři specifické výzkumné otázky.

1. Jaké priority přisuzují učitelé tělesné výchovy současné výuce tohoto školního předmětu?

2. Jaké didaktické ř́idicí styly, v jakých výukových situacích a s jakou osobní zkušeností učitelé využívají?

3. Z jakých zdrojů čerpají učitelé informace o didaktických řídicích stylech a jejich aplikaci ve výuce?

4. Jak učitelé přistupují k možnostem různých didaktických postupů v konkrétní situaci?

\section{Úkoly}

Z položených výzkumný otázek pro nás vyplynula následující posloupnost úkolů.

1. Vytvořit scénář strukturovaného interview s učiteli.

2. Oslovit učitele, kteří se účastnili CPV videostudie tělesné výchovy a získat je pro spolupráci.

3. U učitelů, kteří souhlasí s realizací interview vybrat $\mathrm{z}$ natočeného videomateriálu ukázku pro poslední část interview. 
4. Vytvořit kategoriální systém pro analýzu realizovaných interview.

5. Realizovat domluvená interview.

6. S pomocí kategoriálního systému analyzovat interview.

7. Zpracovat a interpretovat výsledky této analýzy.

\section{METODIKA}

\section{Charakteristika výzkumného souboru}

Výzkumný vzorek pro naše šetření byl vybrán z dvaceti učitelů, kteří se zúčastnili projektu CPV videostudie tělesné výchovy a byly tedy zahrnuti i do první části našeho výzkumu. $K$ využití původního výzkumného vzorku nás vedl zájem použít $\mathrm{k}$ analyzování postojů vůči didaktickým řídicím stylům natočené videozáznamy. Abychom byli schopni naplnit stanovený cíl výzkumného šetření, stanovili jsme si pro výběr učitelů následující kritéria:

1. Učitel aprobovaný pro výuku tělesné výchovy (interview bylo zaměřeno na znalost a využívání spektra didaktických řídicích stylů, přičemž u učitele neaprobovaného bylo dopředu vysoce pravděpodobné, že tuto teorii nebude znát).

2. Aktivní učitel tělesné výchovy (záměrem bylo mimo jiné zjištování osobních zkušeností s aplikací didaktických řídicích stylů, což je snazší v případě aktivního výkonu učitelské profese, rozpomínání neaktivního učitele by mohlo být do jisté míry nepřesné a zavádějící).

Na základě těchto kritérií byli osloveni všichni učitelé původního výzkumného vzorku, kteří je splňovali. Jednalo se o 10 učitelů, z nichž 5 reagovalo kladně a souhlasili s účastí na interview, 1 reagoval záporně a 4 nereagovali vůbec (a to ani na opakované žádosti). Do výzkumného šetření se tedy nakonec zapojilo pouze 5 učitelů a to učitelé vedení $\mathrm{v}$ rámci $\mathrm{CPV}$ videostudie tělesné výchovy pod písmeny $\mathrm{A}, \mathrm{F}, \mathrm{J}, \mathrm{N}$ a $\mathrm{O}$. Jde o 3 ženy a 2 muže, základní charakteristiku těchto učitelů uvádí tab. 1.

Tab. 1: Učitelé, kteří se zapojili do výzkumného šetření

\begin{tabular}{|c|c|c|}
\hline Učitel & Pohlaví & Let praxe \\
\hline Tv_A & žena & 38 \\
\hline Tv_F & muž & 27 \\
\hline Tv_J & žena & 21 \\
\hline Tv_N & žena & 20 \\
\hline Tv_O & muž & 19 \\
\hline
\end{tabular}

\section{Metoda sběru dat}

Jako metoda sběru dat bylo tedy použité strukturované interview. Ale protože bylo naším záměrem získané odpovědi dále rozvíjet a pronikat tak do hlubších úrovní myšlenkových procesů učitelů, použili jsme modifikaci strukturovaného interview, kterou Hendl označuje jako strukturované interview s otevřenými otázkami (Hendl, 2005, s. 173-174). Jednotlivá interview byla realizována v období prosinec 2014 až únor 2015.

Celé interview bylo rozděleno na čtyři části, ve shodě s členěním specifických výzkumných otázek. Na první část, týkající se priorit ve výuce tělesné výchovy, odpovídali všichni dotazovaní. Druhou částí, zaměřenou na samotné didaktické řídicí styly, na postoje k nim a na zkušenosti s nimi, procházeli rovněž všichni, ovšem byly zde nachystané dvě možné linie. Jedna pro ty, kteří znají teorii didaktických řídicích stylů, a lze od nich získávat informace přímo prostřednictvím pojmů spektra. Druhá, ve které bylo dopředu počítáno s možností, že učitel nebude teorii spektra znát a potřebné informace tedy od něho bude nutné získávat pomocí opisů. Tato dvojí př́íprava se nakonec ukázala jako skutečně nezbytná. Třetí část, zjištující zdroje informací o spektru di- 
daktických řídicích stylů by potom byla realizována samozřejmě pouze s těmi, kterým je teorie spektra známa.

Čtvrtá část tvořila závěrečný a specifický díl celého interview. Každému dotazovanému učiteli byla nejprve promítnuta krátká videoukázka jeho výuky, získaná z videomateriálů CPV videostudie tělesné výchovy a následně byla nad touto konkrétní situací vedena za pomoci připravených otázek diskuse o výhodách a nevýhodách toho konkrétního způsobu didaktického zprostř̌edkování učiva a případně možnostech jeho alterování. Ukázky byly vybírány tak, aby poskytovaly určitý prostor pro změnu provedení (nikoli po obsahové, ale po didaktické stránce). Smyslem tedy bylo zjistit, jak učitel o konkrétní situaci přemýšlí, zda si uvědomuje př́ípadné alternativní možnosti, zda je k nim otevřený a ochotný, pokud ne, tak proč, co ho k tomu vede atd. Kompletní scénář použitého strukturovaného interview uvádí tab. 2.

Tab. 2: Scénář strukturovaného interview

\section{Pohled učitelů na aktuální priority ve výuce tělesné výchovy.}

a) Co vy osobně považujete v současné výuce tělesné výchovy za stěžejní, na co by se měla výuka nejvíce zaměřit (jak po stránce obsahové, tak po stránce didaktické)?

b) Zkuste zhodnotit jestli a jakým způsobem se tyto vaše priority promítají do výuky (např. volbou forem, metod, četností určitého obsahu apod.)?

c) Jste na základě vaši praxe a zkušeností přesvědčen(a), že by měly být doplněny, př́ipadně upraveny i formální výstupy tělesné výchovy (tedy výstupy v RVP)? (pokud ANO, pokračovat dále, pokud NE, prejít na oddíl 2)

d) Jaké změny byste tedy do RVP zahrnul(a) a jaké důvody vás $\mathrm{k}$ nim vedou?

2. Využivání didaktických řídicích stylů ve výuce.

a) Je vám v souvislosti s výukou tělesné výchovy a její didaktikou znám pojem didaktický ŕídicí styl? (pokud ANO, pokračovat dále, pokud NE, navázat písmenem l)

b) Jaké didaktické řídicí styly se vám právě ted’ vybavuji? Pokud se vám nevybavuje přesný název stylu, stačí jej stručně charakterizovat.

c) A setkal(a) jste se někdy se stylem ...? (doplnit ty styly, které nebyly zmíněny v předchozí odpovédi)

d) Z formálního hlediska jsou didaktické ŕídicí styly řazeny podle určité logiky na škále, kterou nazýváme Spektrum didaktických rrídicích stylů. Dokázal(a) byste mi svými slovy popsat jakým způsobem, podle čeho jsou zde seřazeny?

e) Zkusil(a) byste seřadit styly, které jste zmínil(a) v úvodu tohoto oddílu, $v$ pořadí, ve kterém jsou seřazeny na spektru?

f) Když plánujete výuku, přemýšlíte cíleně i o tom, jaké didaktické rídicí styly v dané hodině pro cvičení využijete? (pokud ANO, pokračovat pismenem h, pokud NE, pokračovat dále)

g) A máte pro jejich nezahrnutí do plánování výuky nějaký konkrétní důvod?

h) Nyní mi zkuste říci, jaké $\mathrm{z}$ vámi uvedených stylů aktivně využíváte ve své výuce?

i) Mohl(a) byste ke každému zmíněnému stylu připojit i nějaký konkrétní přiklad, který se vám $\mathrm{z}$ výuky vybaví?

j) V jakých výukových situacích použiváte ... styl nejčastěji a jak se vám tento styl ve výuce osvědčil? (zopakovat pro všechny uvedené styly, pokud byly uvedeny v̌sechny styly, pokračovat oddílem 3, pokud nebyly uvedeny všechny styly, pokračovat písmenem $k$ )

k) A co ty ostatní zmiňované styly, proč nevyužíváte i je? Máte $\mathrm{k}$ tomu nějaké konkrétní důvody? (pokracovat oddilem 3)

1) Slyšel(a) jste někdy v souvislosti s tělesnou výchovou pojmy příkazový styl, praktický případně úkolový styl, kognitivní práh, styl s objevováním, přenášení rozhodování na žáka?

m) Dáváte ve svých hodinách někdy žákưm možnost o něčem rozhodnout, např. kde cvičení provedou, kdy ho zahájí, kdy ukonči apod.? Mohl(a) byste uvést nějaký konkrétní příklad z vaší výuky? V jakých výukových situacích zařazujete tento způsob nejčastěji a jak se vám ve výuce osvědčil? 
n) Necháváte někdy žáky, aby na základě nějakých kritérií hodnotili cvičení jiného spolužáka, nebo svoje vlastní? Mohl(a) byste uvést nějaký konkrétní příklad z vaší výuky? V jakých výukových situacích zařazujete tento způsob nejčastěji a jak se vám ve výuce osvědčil?

o) Dáváte někdy žákům možnost, aby si zvolili obtížnost nějakého cvičení, např. výšku kozy při přeskoku? Mohl(a) byste uvést nějaký konkrétní příklad z vaší výuky? V jakých výukových situacích zařazujete tento způsob nejčastěji a jak se vám ve výuce osvědčil?

p) Pokládáte někdy při výuce žákům otázky ve snaze, aby $\mathrm{k}$ zamýšlenému řešení nějaké situace či cvičení došli sami prostřednictvím odpovědí? Mohl(a) byste uvést nějaký konkrétní příklad z vaší výuky? V jakých výukových situacích zařazujete tento způsob nejčastěji a jak se vám ve výuce osvědčil?

q) Necháváte někdy žáky, aby sami hledali řešení nějakého úkolu pouze na základě vašeho zadání? Mohl(a) byste uvést nějaký konkrétní příklad z vaší výuky? V jakých výukových situacích zařazujete tento způsob nejčastěji a jak se vám ve výuce osvědčil?

r) Dáváte někdy žákům možnost, aby si vámi určené téma samostatně připravili (identifikovali postupy, stanovili kritéria, rozhodli a organizaci atd.) a následně realizovali? Mohl(a) byste uvést nějaký konkrétní př́klad $\mathrm{z}$ vaši výuky? V jakých výukových situacích zařazujete tento způsob nejčastěji a jak se vám ve výuce osvědčil? (pokračovat oddilem 4)

\section{Zdroje informací o didaktických ř́íicích stylech.}

a) Vzpomněl(a) byste si, kde jste se se spektrem didaktických řídicích stylů seznámil(a) poprvé?

b) Byly didaktické řídicí styly součástí i vašeho profesního pedagogického vzdělávání? (pokud ANO, pokračovat dále, pokud NE, pokračovat písmenem d)

c) V jaké podobě jste se zde s nimi setkal(a), čistě teoretické, nebo s nimi bylo aktivně pracováno i při nějaké praktické výuce?

d) Zajímal(a) jste se někdy o nové poznatky, zkušenosti a informace o didaktických řídicích stylech a jejich praktickém využití po skončení vysokoškolského studia? (pokud ANO, pokračovat dále, pokud NE, pokračovat oddílem 4)

e) A vzpomenete si, z jakých konkrétních zdrojů jste tyto poznatky a informace čerpal(a)?

\section{Př́stup $\mathrm{k}$ možnostem různých didaktických postupů v konkrétní situaci.}

Oddilu 4 predcházi promítnutí krátké video ukázky z výuky daného učitele, pořizené v rámci videostudie tělesné výchovy.

a) Je to váš obvyklý způsob realizace takovéto výukové situace, nebo ji řešite i didakticky jinak? (pokud to je obvyklý způsob, pokračovat dále, pokud řeši i didakticky jinak pokračovat písmenem $h$ )

b) Mohl(a) byste specifikovat, proč volíte právě tento způsob, např. jaký přinos, jaká pozitiva v něm vidíte?

c) A jste si vědom(a) i nějakých negativ, komplikací, překážek?

d) Dovedl(a) byste si alespoň představit realizaci takovéto výukové situace i jiným didaktickým způsobem? (pokud ANO, pokračovat dále, pokud NE, pokračovat písmenem g)

e) Napadá vás nyní nějaký takový jiný způsob provedení, uměl(a) byste jej popsat trochu konkrétněji?

f) A vnímáte tento způsob realizace jako možný a vhodný pro vaši výuku? Pokuste se uvést důvody proč ano a proč ne. (KONEC)

g) Co vám v tom brání, má to nějaké konkrétní důvody v podobě např. podmínek výuky, kázně žáků apod.? (KONEC)

h) Mohl(a) byste mi bliže popsat, jak jinak didakticky tuto situaci řešite?

i) Uměl(a) byste specifikovat, podle čeho volíte jeden či druhý didaktický způsob provedení, tedy jestli jak bylo zaznamenáno na videu, či právě popsaným způsobem?

j) V čem na základě svých zkušeností spatřujete přednosti a co vnímáte naopak jako možnou komplikaci způsobu zaznamenaného videu?

k) A v čem na základě svých zkušeností spatřujete přednosti a co vnímáte jako možnou komplikaci u toho popsaného způsobu? (KONEC) 
Z každého provedeného interview byla se souhlasem př́slušného učitele pořízena digitální nahrávka pro potřeby následné transkripce.

\section{Metoda zpracování a analýzy dat}

Získané digitální nahrávky jednotlivých interview byly převedeny do podoby zvukových souborů a připraveny na následnou analýzu. Pro potřebu této analýzy byl vytvořen kategoriální systém, který prezentuje tab. 3. Jednotlivé kategorie tohoto systému byly následně vloženy do programu Videograph, ve kterém byl zvukový záznam interview kódován. Pomocí kódování jsme identifikovali a roztř́idili klíčová data, která jsme následně podrobili obsahové analýze a vzájemnému porovnání.

Tab. 3: Kategoriální systém pro kódování strukturovaného interview

\begin{tabular}{|c|c|c|}
\hline Kategorie & Subkategorie & Obsahové vymezení \\
\hline \multirow[t]{5}{*}{$\begin{array}{l}1.1 \text { Priority } \\
\text { ve výuce TV }\end{array}$} & $\begin{array}{l}\text { 1.1.1 Vytvoření či posílení } \\
\text { pozitivního vztahu } \\
\text { k pohybu jako součásti } \\
\text { života }\end{array}$ & $\begin{array}{l}\text { Učitel uvádí, že za prioritu ve výuce TV považuje vytvoření } \\
\text { či posílení pozitivního vztahu k pohybu jako takovému, tedy } \\
\text { že žáci budou svůj pohybový režim aktivně plánovat a řídit, } \\
\text { cíleně využivat ke konkrétním záměrům a emočně pozitivně } \\
\text { proživat (mít radost z pohybu). }\end{array}$ \\
\hline & $\begin{array}{l}\text { 1.1.2 Zdravotně orientovaná } \\
\text { zdatnost }\end{array}$ & $\begin{array}{l}\text { Učitel uvádí, že jeho pojetí výuky TV směřuje k uvědomělé- } \\
\text { mu využívání pohybu jako prostředku zdravotní prevence, } \\
\text { případně korekce, tedy že žáci cíleně usilují o zlepšení své } \\
\text { zdatnosti, jsou schopni se na pohybovou aktivitu řádně při- } \\
\text { pravit a ukončit ji v souladu s charakterem zátěže, odmítají } \\
\text { drogy a jiné škodlivé látky a předvídají možná rizika úrazu } \\
\text { a předchází jim. }\end{array}$ \\
\hline & $\begin{array}{l}\text { 1.1.3 Rozvoj motorických } \\
\text { schopností } \\
\text { a pohybových } \\
\text { dovedností }\end{array}$ & $\begin{array}{l}\text { Učitel uvádí, že jeho prioritou při výuce TV je zajistit rozvoj } \\
\text { motorických schopností a pohybových dovedností žáků tak, } \\
\text { aby vzhledem ke svým individuálním možnostem a předpo- } \\
\text { kladům maximálně využili potenciál činností, realizovaných } \\
\text { ve výuce a sami dokázali jednotlivé činnosti popsat a posou- } \\
\text { dit přednosti a nedostatky provedení i s uvedením př́ičin } \\
\text { případných nedostatků. }\end{array}$ \\
\hline & $\begin{array}{l}\text { 1.1.4 Budování a upevñování } \\
\text { volních a morálních } \\
\text { vlastností osobnosti } \\
\text { žáka }\end{array}$ & $\begin{array}{l}\text { Učitel uvádí, že jeho hlavním cílem je prostřednictvím po- } \\
\text { hybových činností budovat a dále upevñovat volní a morální } \\
\text { vlastnosti každého žáka ve smyslu naplňování pravidel fair } \\
\text { play a olympijských myšlenek, dodržování pravidel spor- } \\
\text { tovních disciplín, přiměřené zvládání složitějších komuni- } \\
\text { kačních situací atd. }\end{array}$ \\
\hline & $\begin{array}{l}\text { 1.1.5 Bez individuálních } \\
\text { priorit }\end{array}$ & $\begin{array}{l}\text { Učitel uvádí, že pro výuku TV nemá žádné výrazné priority, } \\
\text { jeho zájem je relativně rovnoměrně rozvržen mezi všechny } \\
\text { formální cíle TV dle RVP ZV. }\end{array}$ \\
\hline \multirow[t]{4}{*}{$\begin{array}{l}1.2 \text { Aplikace priorit } \\
\text { do procesu výuky }\end{array}$} & 1.2.1 Didaktická rovina & $\begin{array}{l}\text { Učitel uvádí, že jeho priority ovlivňují hlavně didaktickou } \\
\text { stránku jeho výuky, tedy že mají vliv hlavně např. na volbu } \\
\text { cílů, organizačních forem, vyučovacích metod, vyučovacích } \\
\text { postupů. }\end{array}$ \\
\hline & 1.2.2 Obsahová rovina & $\begin{array}{l}\text { Učitel uvádí, že jeho priority mají vliv především na výběr } \\
\text { vzdělávacího obsahu a kvantitu jeho zařazování. }\end{array}$ \\
\hline & 1.2.3 Osobní rovina & $\begin{array}{l}\text { Učitel uvádí, že jeho priority se ve výuce projevuji v podobě } \\
\text { jeho osobního příkladu nebo příkladu někoho význačného. }\end{array}$ \\
\hline & 1.2.4 Neutrální rovina & $\begin{array}{l}\text { Učitel uvádí, že není schopen zhodnotit jestli, a jakým způ- } \\
\text { sobem se jeho priority ve výuce projevují. }\end{array}$ \\
\hline
\end{tabular}




\begin{tabular}{|c|c|c|c|}
\hline \multirow[t]{4}{*}{$\begin{array}{l}1.3 \text { Doplnění } \\
\text { a úprava } \\
\text { formálních } \\
\text { výstupů TV }\end{array}$} & 1.3 .1 & $\begin{array}{l}\text { Záporný } \\
\text { postoj }\end{array}$ & $\begin{array}{l}\text { Učitel uvádí, že podle jeho názoru není v současné době } \\
\text { potřeba formální výstupy TV doplňovat ani upravovat v žád- } \\
\text { ném směru. }\end{array}$ \\
\hline & 1.3 .2 & $\begin{array}{l}\text { Kladný postoj } \\
\text { z pohledu zdraví }\end{array}$ & $\begin{array}{l}\text { Učitel uvádí, že je přesvědčen o potřebě doplnění či úpravy } \\
\text { v oblasti činností ovlivňujících zdraví. }\end{array}$ \\
\hline & 1.3 .3 & $\begin{array}{l}\text { Kladný postoj } \\
\text { z pohledu } \\
\text { pohybových dovedností }\end{array}$ & $\begin{array}{l}\text { Učitel uvádí, že je přesvědčen o potřebě doplnění či úpravy } \\
\text { v oblasti činností ovlivňujících úroveň pohybových doved- } \\
\text { ností. }\end{array}$ \\
\hline & 1.3 .4 & $\begin{array}{l}\text { Kladný postoj } \\
\text { z pohledu } \\
\text { podporujících činností }\end{array}$ & $\begin{array}{l}\text { Učitel uvádí, že je přesvědčen o potřebě doplnění či úpravy } \\
\text { v oblasti činností podporujících pohybové učení. }\end{array}$ \\
\hline \multirow[t]{4}{*}{$\begin{array}{l}\text { 2.1 Znalost teorie } \\
\text { Dřs }\end{array}$} & 2.1 .1 & Neznalý & $\begin{array}{l}\text { Učitel uvádí, že pojem DŘS mu nic neříká a neuvědomuje } \\
\text { si, že by o něm někdy slyšel. }\end{array}$ \\
\hline & 2.1 .2 & Obeznámený & $\begin{array}{l}\text { Učitel uvádí, že obsahovou stránku DŘS není schopen } \\
\text { konkrétně specifikovat, ale uvědomuje si, že se s takovým } \\
\text { pojmem někdy setkal. }\end{array}$ \\
\hline & 2.1 .3 & Poučený & $\begin{array}{l}\text { Učitel uvádí, že s pojmem DŘS se již setkal a je schopen } \\
\text { uvést nebo charakterizovat alespoň některé z DŘS. }\end{array}$ \\
\hline & 2.1 .4 & Znalý & $\begin{array}{l}\text { Učitel uvádí, že pojem zná a je schopen charakterizovat } \\
\text { všechny nebo téměř všechny DŘS, uvést vztahy mezi nimi, } \\
\text { logiku řazení na spektru a další podrobnosti. }\end{array}$ \\
\hline \multirow[t]{2}{*}{$\begin{array}{l}2.2 \text { Práce s DŘS } \\
\text { při plánování } \\
\text { výuky }\end{array}$} & 2.2 .1 & Plánuje & $\begin{array}{l}\text { Učitel uvádí, že obvykle při plánování své výuky cíleně roz- } \\
\text { mýšlí i jaké DŘS využije. }\end{array}$ \\
\hline & 2.2 .2 & Neplánuje & $\begin{array}{l}\text { Učitel uvádí, že při plánování své výuky cíleně nerozmýšlí } \\
\text { jaké DŘS využije. }\end{array}$ \\
\hline \multirow[t]{7}{*}{$\begin{array}{l}2.3 \text { Využívané } \\
\text { DŘS }\end{array}$} & 2.3 .1 & Příkazový & $\begin{array}{l}\text { Učitel uvádí, že v určitých výukových situacích řídí veškerou } \\
\text { činnost svých žáků prostřednictvím povelů a pokynů. }\end{array}$ \\
\hline & 2.3 .2 & Praktický & $\begin{array}{l}\text { Učitel uvádí, že v určitých výukových situacích nechává } \\
\text { své žáky dělat dílčí rozhodnutí (např. zvolit místo cvičení, } \\
\text { rozhodnout o zahájení a ukončení cvičení, zvolit si tempo } \\
\text { cvičení atd.). }\end{array}$ \\
\hline & 2.3 .3 & Reciproční & $\begin{array}{l}\text { Učitel uvádí, že v určitých výukových situacích nechává } \\
\text { žáky, aby podle předem připravených kritérií hodnotili cvi- } \\
\text { čení svých spolužáků. }\end{array}$ \\
\hline & 2.3 .4 & Se sebehodnocením & $\begin{array}{l}\text { Učitel uvádí, že v určitých výukových situacích nechává } \\
\text { žáky, aby podle předem připravených kritérií hodnotili svůj } \\
\text { provedený výkon. }\end{array}$ \\
\hline & 2.3 .5 & S nabídkou & $\begin{array}{l}\text { Učitel uvádí, že v určitých výukových situacích mají žáci } \\
\text { možnost vybrat si z připravených variant stupeň obtíżnosti } \\
\text { provedení určitého cvičení. }\end{array}$ \\
\hline & 2.3 .6 & S rrízeným objevováním & $\begin{array}{l}\text { Učitel uvádí, že v určitých výukových situacích vede své } \\
\text { žáky ke stanovenému cíli prostřednictvím předem promyš- } \\
\text { lených otázek, které žákům postupně klade v určitém pořadí } \\
\text { a na něž žáci sami hledají odpověd'. }\end{array}$ \\
\hline & 2.3 .7 & $\begin{array}{l}\text { S přímočarým } \\
\text { objevováním }\end{array}$ & $\begin{array}{l}\text { Učitel uvádí, že v určitých výukových situacích zadává žá- } \\
\text { kům jeden cíl, kterého mají dosáhnout a zároveň jim dá } \\
\text { jeden vstupní podnět (problém, otázku, situaci), který je má } \\
\text { k dosažení cíle nasměrovat. Žáci pak řeši problém (dosažení } \\
\text { cíle) samostatně. }\end{array}$ \\
\hline
\end{tabular}




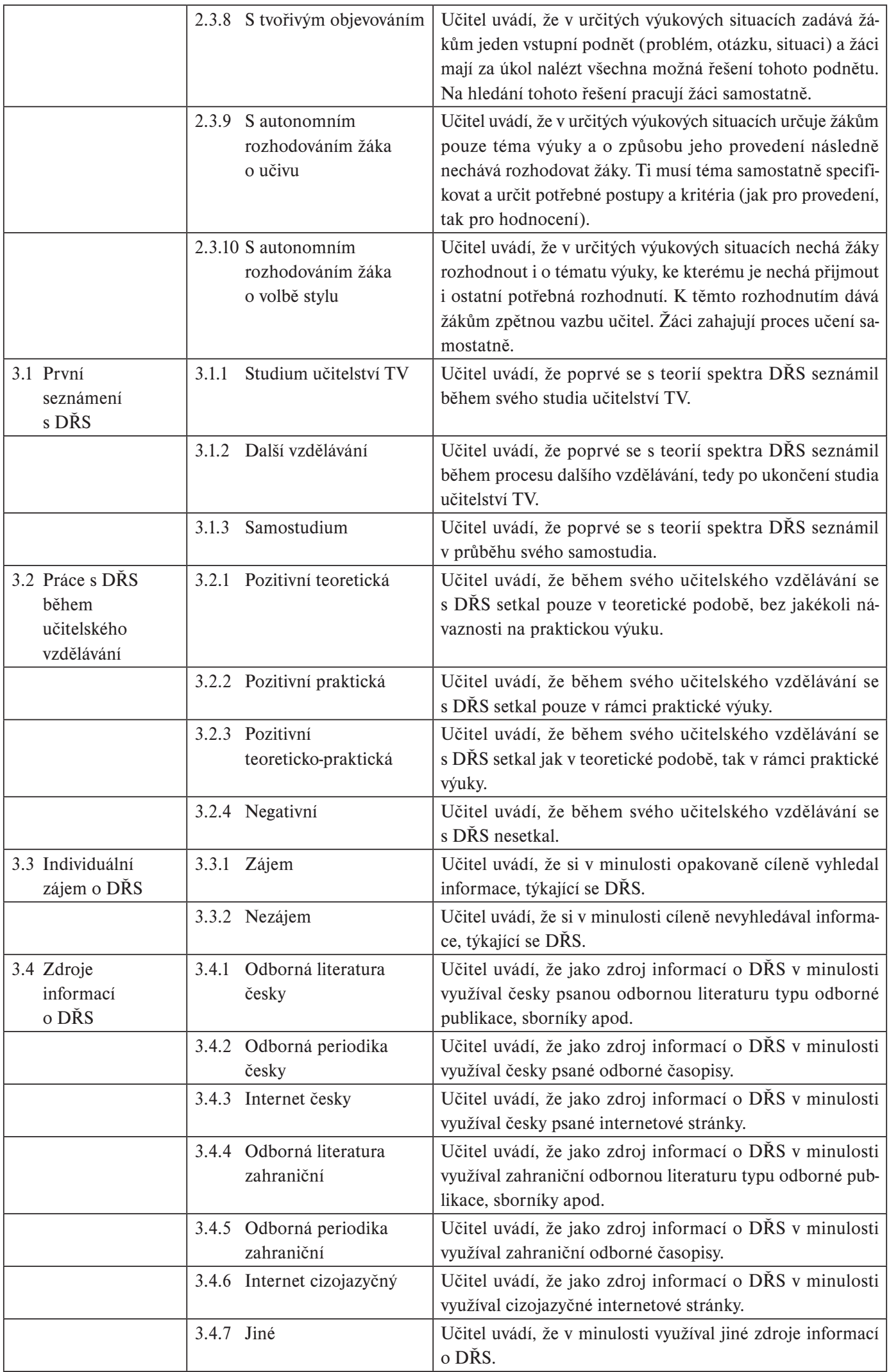




\begin{tabular}{|l|l|l|}
\hline $\begin{array}{c}4.1 \text { Využití } \\
\text { určitého DŘS } \\
\text { v konkrétní } \\
\text { situaci }\end{array}$ & 4.1 .1 Obvyklý způsob & $\begin{array}{l}\text { Učitel uvádí, že situaci zobrazenou na videozáznamu řeši } \\
\text { didakticky zpravidla tímto způsobem. }\end{array}$ \\
\hline & 4.1 .2 Jeden ze způsobů & $\begin{array}{l}\text { Učitel uvádí, že situaci zobrazenou na videozáznamu řeší } \\
\text { za určitých podmínek i jiným didaktickým způsobem. }\end{array}$ \\
\hline 4.2 Vize změny & 4.2 .1 Uskutečnitelná & $\begin{array}{l}\text { Učitel uvádí, že si dokáže představit provedení dané výukové } \\
\text { situace i jiným didaktickým způsobem. }\end{array}$ \\
\hline & 4.2 .2 Neuskutečnitelná & $\begin{array}{l}\text { Učitel uvádí, že si nedokáže představit provedení dané vý- } \\
\text { ukové situace jiným didaktickým způsobem. }\end{array}$ \\
\hline
\end{tabular}

\section{VÝSLEDKY}

V oblasti osobního pohledu na priority současné tělesné výchovy se učitelé $\mathrm{A}, \mathrm{F}$ a $\mathrm{N}$ shodli na nutnosti vytvoření či posílení pozitivního vztahu k pohybu.

„A: Já bych je asi chtěla dovést k tomu, že mají mět ten sport rádi. “"

„F: Úplně nej, nej, nej, je otázka vzbudit zájem u žactva, u dětí, aby skutečně ten sport byl pro ně hobby a byl každodenní..."

„N: Co je pro mě nejdůležitějš́ - aby se těch pětačtyřicet minut hýbali a aby je to bavilo, aby jim ten zájem o ten pohyb zůstal co nejdéle."

Učitelka $\mathrm{N}$ ještě navíc připojila priority v oblasti zdatnosti, $\mathrm{v}$ čemž ji podpořila i učitelka $\mathrm{J}$.

"N: Strašně moc hraju různé věci na rozvoj kondice."

„J: ... a fyzická zdatnost, protože opravdu vyjdou do druhého patra a jsou unavení.“

Společně s učitelem $\mathrm{O}$ se pak ještě obě dvě předchozí shodly na potřebě rozvoje pohybových schopností a dovedností.

„O: V̌̃estrannost, jedním slovem všestrannost.“

„N: Všestranost. Všestranost a pres hry v̌̌estrannost."

„J: Rozvoj pohybových schopností, koordinace, určité základy bezpečnosti, techniky pádu...“

Tyto své priority následně realizují učitelé ve svých hodinách převážně prostřednictvím volby obsahu - pestrost, četnost, efektivita. Učitelka N ještě přidává navíc cenný osobní př́klad, jehož prostř̌ednictvím se své žákyně snaží motivovat nejen k pohybu, ale hlavně k osobnímu zlepšování.

„N: Jsem sportovec, hraju závodně tenis, bruslim, běhám s nima, skáču, všechno... Mám na ně svůj bič pres sebe."

S ohledem na své priority nemá většina zúčastněných učitelů pocit, že by bylo nezbytné zasahovat i do formálních výstupů tělesné výchovy, tedy do Rámcového vzdělávacího plánu. Pouze učitel F potřebu alespoň určitých změn zmínil.

„F: Stoprocentně, minimálně zpř́snilo tak, aby byly dané v podstatě jasné výstupy, jasné hranice, co to dítě má umèt po absolvování, dejme tomu prvního stupně..."

Dále přišla na řadu zlomová otázka ohledně znalosti teorie spektra didaktických řídicích stylů. Čtyři ze zúčastněných se v tomto bodě vyjádřili v tom smyslu, že jim tento pojem nic neříká, a že si nejsou schopni vybavit, jestli se s ním někdy setkali. Pouze učitelka A si uvědomila, že se během svého vzdělávání s takovým pojmem kdysi pravděpodobně setkala, ale k jeho obsahu se rovněž nedokázala vyjádřit. Připojila však zajímavý dovětek.

„A: No, asi ve škole, no, asi, no. No, já už nevím, já už to mám spís jako zabalený do té praxe, takže já už vám takhle to jako neřeknu. Někde to tam je, ale to už jako, to už je dávno, to už jako spís dostávaj tak jako, že si to třeba ani neuvědomuju, že tento styl jako ted'ka budu chtět dělat, už to tam mají."

Vzhledem k tomu, že teorie spektra didaktických řídicích stylů nebyla nikomu ze zúčastněných známa, byly pochopitelně otázky týkající se práce s didaktickými řídicími styly při plánování výuky přeskočeny. Dále byla ve stěžejní části interview, věnované využívaným didaktickým řídícím stylům a zkušenostem s jejich využiváním, použita pouze druhá, opisná linie otázek. Pro větší přehlednost 
jsme výsledky této části zpracovali do tab. 4. Tabulka zachycuje autentickou podobu jednotlivých výroků o identifikovaných didaktických řídicích stylech a zkušenostech s nimi.

Tab. 4: Didaktické rídicí styly zachycené v interview s jednotlivými učiteli

\begin{tabular}{|c|c|c|}
\hline $\begin{array}{l}\text { Didaktický } \\
\text { ř́dicí styl }\end{array}$ & Popis & Zkušenosti \\
\hline Příkazový styl & $\begin{array}{l}\mathrm{F}: \text {...a to vedou sami, tu rozcvičku... } \\
\mathrm{J}: \text {... jednou mají společné rozcvičování... } \\
\text { frontálně... }\end{array}$ & $\begin{array}{l}\text { F: ...je to ten prvek vystoupit před tím } \\
\text { kolektivem...je to ta komunikační zkuše- } \\
\text { nost... } \\
\text { J: Jsou na to zvyklý... }\end{array}$ \\
\hline Praktický styl & $\begin{array}{l}\text { A: [A můžou si rozhodovat kdy, kam pů- } \\
\text { jdou? }]^{2} \text { Ano, ano. } \\
\text { N: ...kdo je unavený, jde stranou, zase mají } \\
\text { vlastní tempo... }\end{array}$ & $\begin{array}{l}\text { A: ...myslím, že to asi nevnímaj...já si my- } \\
\text { slím, že to tak nějak jako, prostě to berou, } \\
\text { že takhle jsem to vymyslela a tím pádem } \\
\text { to takhle je... } \\
\text { N: ...myslim si, že ta samostatnost a roz- } \\
\text { hodování je pro ně hodně dobré a tvořivé. }\end{array}$ \\
\hline Reciproční styl & $\begin{array}{l}\text { J: Já třeba řeknu, ten, kdo sedí, tak se dívá } \\
\text { na kamaráda, aby mu potom řekl, kde dělá } \\
\text { kamarád chyby. }\end{array}$ & $\begin{array}{l}\text { J: Nemám pocit, že by z toho ty děti měly } \\
\text { nějaké trauma, že by si mezi sebou měly } \\
\text { ríct, že se tomu druhýmu něco nedaří úpl- } \\
\text { ně přesně. }\end{array}$ \\
\hline $\begin{array}{l}\text { Styl s přímočarým } \\
\text { objevováním }\end{array}$ & $\begin{array}{l}\text { J: ...já se tam postavím jako obránce a musí } \\
\text { si oni přijít na to, proč jsem se k míči do- } \\
\text { stala tak snadno... }\end{array}$ & $\begin{array}{l}\text { J: Vždycky v té skupince existujou dvě, tři } \\
\text { děti, který na to jdou přes myšlení, ale vět- } \\
\text { šina těch ostatních jde na to mechanicky } \\
\text { pokus omyl... }\end{array}$ \\
\hline
\end{tabular}

Otázky třetí části interview ohledně informačních zdrojů o spektru didaktických řídicích stylů byly u všech učitelů vynechány, nebot učitelé nebyli s teorií obeznámeni. A otázky čtvrté části, věnované řešení konkrétní výukové situace, nyní shrneme u každého ze zúčastněných učitelů zvlášt̃.

Učitelka A označila didaktickou podobu vybrané situace za svůj obvyklý způsob zprostředkování předmětného učiva. Dokázala na tomto způsobu najít pozitiva, negativa jí žádná nenapadala, což doplnila výrokem: „Asi jsem o tom takhle nepřemýšlela, protože mně to takto vyhovuje. “Možnost jiného didaktického řešení dané situace ji nenapadla, ale doplnila to konstatováním: „Mám to zaběhnutý, mám to ozkoušený, jo, ale řikám, nebráním se tomu, já nevím treba, nějaký nový zpưsob. “

Učitel F rovněž označil vybranou situaci za svůj obvyklý způsob didaktického provedení. Bez většího rozmýšlení dokázal pojmenovat jak klady, tak zápory takového provedení a ani návrh alternativní možnosti mu nedal př́liš práce. Její realizování ve výuce si, dle svých slov, dokáže stoprocentně představit.

Učitelka J charakterizovala svůj pohled na situaci takto: „No, myslim si, že už to mám natolik zafixovaný, že bych řekla, že bych to dneska udělala úplně stejně. "Pozitiva tohoto postupu si uvědomovala stejně dobře jako negativa. A právě s ohledem na ně následně zkonstruovala jinou variantu provedení, jejíž realizování vnímala jako reálně možné.

Učitelka N zhodnotila shlédnutou situaci jako jednu z možných variant, které reálně použivá. Dle okolností je totiž takovouto situaci připravena řešit minimálně dvěma dalšími didaktickými postupy. Způsob výběru př́slušného postupu objasnila na základě popisu výhod každého z nich.

Pro učitele $\mathrm{O}$ byla vybrána ukázka, ve které použivá netradiční tělovýchovné náčiní. Po jejím zhlédnutí konstatoval, že tento druh aktivity již zcela vyřadil ze svého obsahového repertoáru, a že tudíž není schopen posoudit, jak by tuto situaci aktuálně řešil. Konstatoval pouze, že jej k jejímu vyřazení vedlo hledisko bezpečnosti žáků a s tím související jejich zhoršující se kázeň.

\footnotetext{
${ }^{2} \mathrm{~V}$ hranatých závorkách uvedena otázka tazatele.
} 
Pokud máme z nasbíraných dat vybrat ta, která by blíže ozřejmila, proč jsme ve všech pozorovaných hodinách $\mathrm{v}$ rámci první části výzkumu identifikovali pouze př́kazový a praktický styl, jinými slovy, proč nebyla výuka didakticky bohatší, jsou to následující.

Nejčastěji zmíněným faktorem, ovlivňujícím způsob didaktického zprostředkování učiva byla časová náročnost hodiny. Jako př́klad lze uvést reakci učitelky na definici stylu s tvořivým objevováním: „To já jim asi radši řeknu. [Vic času na procvičování?] Ano. “

Dalším možným důvodem pro nezařazování některých didaktických řídicích stylů je potom určitá negativní zkušenost učitele. Malému zájmu se v naší skupině učitelů těšil například styl se sebehodnocení. Jeden z učitelů to komentoval tak, že „...je to taková dost ošidná situace, alespoň co mám zkušenost... “. Podobně pak u stylu recipročního: „Asi bych řekl, že spíš o to nestojí, je to někdy na sílu."

A do třetice může přemýšlení o volbě didaktického řídicího stylu také souviset s určitými tradicemi. Při diskusi o podstatě stylu s nabídkou reagoval jeden z učitelů poměrně striktně: „Ne, na to máme tabulky a na to máme už zase nějaký zažitý mustr. “.

\section{DISKUSE A ZÁVĚR}

Jak jsme konstatovali v úvodu této práce, uvědomujeme si, že výsledky našeho výzkumného šetření nelze jakkoli zobecňovat. Přesto považujeme získané informace, byt’ od pouhých pěti zástupců učitelského stavu, za př́nosné a nevhodné přehlížení, nebot se s nimi vynořují otázky, se kterými bychom se měli vypořádat.

Zúčastnění učitelé ve svých prioritách zopakovali tři nejčastěji diskutované problémy, před jejichž řešení je současná tělesná výchova postavena - vztah mladých lidí k pohybu, úroveň fyzické zdatnosti a úroveň pohybových schopností a dovedností populace. Převažovala mezi nimi však tendence $\mathrm{k}$ řešení těchto problémů skrze obsahovou náplň hodin tělesné výchovy. Měli bychom však při řešení těchto zásadních problémů skutečně vsázet jen na pestrost a atraktivitu? Jsme schopni skrze obsah předat všechny potřebné dovednosti, jako dovednost posouzení vlastní pohybové aktivity, dovednost jejího plánování atp. Jsme přesvědčeni, že minimálně efektivnější bude posílit i ostatní složky výuky, tu didaktickou nevyjímaje.

Podoba kurikula a stav jeho reformy neměl v naší práci hrát hlavní roli, ostatně většina zúčastněných učitelů s ním byla v podstatě spokojena. Dokonce se ztotožňujeme s konstatováním učitele O: „Tím, že nám presně nediktují, budete dělat gymnastiku tohle a tohle, tak to je samozrejmě dobre. ", nebot jsme přesvědčeni, že tělesná výchova by neměla být svázána striktními předpisy, a že by zde do určité míry měl existovat prostor pro seberealizaci jak učitele, tak žáků. Ale v souvislosti s tím je potřeba nezapomínat, že i podoba kurikula, bude vždy do určité míry ovlivňovat možnosti řešení nastíněných problémů.

Celý náš výzkum byl zaměřený na využivání didaktických řídicích stylů ve výuce tělesné výchovy. V jeho samotném závěru jsme se paradoxně setkali s celou jednou čtvrtinou všech zúčastněných a zjistili, že žádný z nich vlastně nemá o předmětu našeho zájmu téměř žádné povědomí. Přináší to s sebou otázku, zda a prípadně jak velký problém by to mohlo pro samotnou praxi znamenat? Je nutné podotknout, že ačkoli zúčastnění učitelé teorii spektra neznali, přesto se během interview objevovali v jejich výpovědích neoddiskutovatelné známky využití i dalších stylů, než které byly identifikovány na videozáznamech. Pouhým rozhovorem jsme je však nemohli všechny ověřit natolik, abychom je uvedli spolu s ostatními v tab. 4. Musíme ale zdůraznit, že se objevovaly prvky směřující nejen ke stylům reprodukční části spektra, tedy hlavně ke stylu se sebehodnocením a s nabídkou, ale i ke stylům za kognitivním prahem, jako např. s řízeným a tvořivým objevováním. Je tedy možné, aby určitý instinktivní a intuitivní př́stup učitele nahradil znalost teorie? Pokud bychom takovou možnost připustili, je potřeba pamatovat na to, že vyučovací činnost učitele je činností záměrnou, plánovanou, a spoléhat při ní pouze na intuici a instinkty považujeme za nedostatečné (toto konstatování klademe čistě do obecné roviny, rozhodně se nechceme jakkoli dotknout kvality práce a zodpovědnosti kohokoli ze zúčastněných učitelů). Znalost teorie, všech 
faktorů, rizik, podmínek apod., vybavuje učitele všemi potřebnými nástroji pro efektivní řízení výuky. Dovoluje tak, podle našeho názoru, dosahovat větší úspěšnosti didaktického procesu ve výuce. Stejně tak si ovšem uvědomujeme, že teorie sama o sobě kvalitní výuku pochopitelně nezajistí.

Důležité do budoucna bude dokázat se vypořádat s uvedenými, př́ípadně i dalšími, připomínkami učitelů ke způsobům didaktického zprostředkování učiva. Jsme přesvědčeni, že argumenty jsou zřejmé. Cvičební čas žáků by v některých př́ípadech podle našeho názoru mohl ustoupit rozvoji jiných, než jejich fyzických stránek. Poznatek, že určitá skupina žáků není schopna v některém didaktickém ř́dicím stylu pracovat (což je vzhledem např. $\mathrm{k}$ bezpečnostním faktorům samozřejmě reálně možné), by neměl vést $\mathrm{k}$ zobecnění, že v tomto stylu není schopna pracovat žádná skupina žáků. Rovněž tradice nepovažujeme za neprolomitelné, vždyt̉ naši žáci se mění, mění se jejich potřeby, mění se priority společnosti a nato vše bychom měli být schopni reagovat i v tělesné výchově. Změnu tohoto myšlení považujeme za výzvu především pro oblast učitelského vzdělávání, a to jak tu primární na vysokých školách, tak i tu následnou ve formě dalšího vzdělávání učitelů.

A že je taková změna možná dokazují i učitelé z našeho výzkumného šetření. Ti sice na jedné straně měli tendence $\mathrm{k}$ určitému tradicionalismu, k neopouštění zažitých a osvědčených postupů, tedy k tomu, co tvůrce teorie spektra didaktických řídicích stylů Muska Mosston (2008) nazval idiosynkraziemi. Na straně druhé však rovněž prokazovali ochotu přemýšlet o předestřených problémech, hledat možná řešení a zamýšlet se nad jejich významem. Při dostatečné znalosti potřebných principů a při odpovídajícím praktickém výcviku, vedoucímu k upevnění především sebejistoty a určitého nadhledu, považujeme širší využíání různých didaktických řídicích stylů za reálné a žádoucí.

\section{Seznam literatury}

Dobrý, L. (2007). Změna činnosti učitele je hlavní podmínkou úspěchu naší školské reformy. Tělesná výchova a sport mládeže: odborný časopis pro učitele, trenéry a cvičitele, 73 (3), 8-15.

Hendl, J. (2005). Kvalitativní výzkum: základní metody a aplikace. Praha: Portál.

Janík, T. (2007). Cílová orientace ve výuce fyziky: exkurz do subjektivních teorií učitelů. Pedagogická orientace, 17 (1), 12-33.

Mosston, M., \& Ashworth, S. (2008). Teaching Physical Education: First Online Edition. Retrieved from: http://www.spectrumofteachingstyles.org/ebook

Mužík, V., \& Hurychová, A. (1994). Knovému pojetí didaktiky tělesné výchovy. Brno: Masarykova univerzita.

Rychtecký, A., \& Fialová, L. (2004). Didaktika školní tělesné výchovy. Praha: Karolinum.

Salvara, M. I., LeBlanc, H., Bognár, J. \& Biro, E. N. (n.d.). The Effect of Postgraduate Studies on Elementary School Physical Education Teachers' Perceptions for Overall Pupils' Development Using Ten Teaching Styles. Retrieved from: http:// spectrumofteachingstyles.org/pdfs/literature/Salvara_et_al.pdf

Sliacky, J., \& Janíková, M. (2013). Spektrum didaktických řídicích stylů ve výuce tělesné výchovy na 2. stupni základní školy. Studia sportiva, 9 (1), 81-97.

Tomajko, D., \& Dobrý, L. (2002). Didaktické styly a metodicko-organizační formy jako základ vyučování pohybových her. Tělesná výchova a sport mládeže: odborný časopis pro učitele trenéry a cvičitele, 68 (4), 26-33. 